\title{
THE PRODUCTION OF NOVEL FUNCTIONAL YOGHURT CONTAINING ANGIOTENSIN I-CONVERTING ENZYME (ACE)-INHIBITORY ACTIVITY
}

\author{
Mohamed B. El-Alfy $^{1 *}$, M.E. Shenana ${ }^{1}$, M.A. Abd-El-Aty ${ }^{1}$, A.E. Yousef ${ }^{2}$ and E.S. Elkhtab ${ }^{1}$ \\ 1. Dairy Sci. Dept., Fac. Agric., Benha Univ., Egypt \\ 2. Food Sci. and Technol. Dept., Coll. Food, Agric. and Environ. Sci., Ohio State Univ., USA
}

\begin{abstract}
Novel functional types of yoghurt containing ACE-inhibitory activity were produced by adding Lactobacillus casei ATCC 7469, Lb. paracasei 6A and kombucha besides the yoghurt starter cultures in order to increase the activity against the ACE. Results showed that the ACE-inhibitory activity increased during the cold storage periods at $4^{\circ} \mathrm{C}$ for 28 days. Soluble nitrogen was increased during the cold storage periods. The chemical analysis data of the produced novel functional yoghurt were similar to that of control. Same observations were for the microbiological examination. Also, the water holding capacity and firmness of the novel functional yoghurt were good as the control up to the end time of the experimental design.
\end{abstract}

Key words: Novel functional yoghurt, ACE-inhibitory, probiotic, Lb. casei ATCC 7469, $L b$. paracasei $6 \mathrm{~A}$ and kombucha.

\section{INTRODUCTION}

Yoghurt is one of the most important fermented dairy products. Due to its high nutritional importance, which is well known, also its different types and flavours which gives these products a wide spread between consumers. The beneficial health and functional effects of yoghurt can be increased by different ways based on the peptides that are produced during fermentation and storage of such product. Many peptides with antihypertensive action have been characterized upon fermentation of milk with different microorganisms, or by the action of proteinases on milk proteins. The peptides are not active within the parent protein but can be released and activated with enzymatic hydrolysis (FitzGerald and Meisel, 2003).

Bioactive peptides may act in the body as regulatory components with a hormone-like activity which may modulate specific physiological functions in the human body (Meisel and FitzGerald, 2003). In addition, multi-functional bioactive effects have been identified within specific casein sequences, for example angiotensin-converting enzymes (ACE)inhibitory activities (Migliore-Samour and Jolles, 1988). Biologically, active peptides can be produced from precursor milk protein using different ways i.e. (a) enzymatic hydrolysis by digestive enzymes (b) fermentation of milk with proteolytic starter cultures and (c) proteolysis by enzymes derived from microorganisms or plants. In many studies a combination of above methods has proven effective in generation of short functional peptides (Korhonen and Pihlanto, 2003).

Many dairy starter cultures are highly proteolytic formation of bioactive peptides can, thus, be expected during the manufacture of fermented dairy products.

Yoghurt bacteria, cheese starter bacteria and commercial probiotic bacteria have been demonstrated to produce different bioactive peptides in milk during fermentation (GomezRuiz et al., 2002; Fuglsang et al., 2003; Gobbetti et al., 2004; Donkor et al., 2005).

\footnotetext{
*Corresponding author: Tel. : +201222539638

E-mail address: Mbelalfy@fagr.bu.edu.eg
} 
Nowadays, people became more aware about their health i.e. (obesity, chronic diseases.. etc.). The probiotics and synbiotics have occupied an important sector with the functional dairy foods market. Most of the functional foods are from dairy products (Vasudha and Mishra, 2013). The new trend is to use nondairy probiotics i.e., kombucha (fermented green tea) or in association with dairy products in order to increase the power of probiotics in the products.

The potential health benefits of bioactive milk peptides have been a subject of growing commercial interest in the context of healthpromoting functional dairy foods. So far, antihypertensive, mineral-binding and anti carcinogenic peptides have been most studied for their physiological effects (Korhonen, 2009).

Hence, the aim of the present study was to produce novel functional yoghurt, with new properties either during the fermentation or the refrigerated storage and measure the proteolysis and the ACE- inhibitory activity of the novel functional yoghurt.

\section{MATERIALS AND METHODS}

\section{Materials}

\section{Raw milk}

Cow's raw milk, (4\% fat and $13.6 \%$ TS) was obtained from a dairy farm (The Ohio State University, Columbus, OH, USA) and used for the novel functional yoghurt making.

\section{Starter cultures}

Frozen yoghurt starter pellets (F-DVS YoFlex, Mild 2.0) containing Streptococcus thermophilus and Lactobacillus delbrueckii subsp. bulagaricus (Chr. Hansen) were obtained friendly from Dept. of Food Sci. and Technol., OSU. This starter was added at a rate of $1 \mathrm{~g} /$ $1000 \mathrm{ml}$ of milk. Lactobacillus casei ATCC 7469 and $L b$. paracasei 6A were obtained from the culture collection of the Food Microbiology Laboratory of the Ohio State University, Columbus, Ohio and Kombucha was purchased from Kombucha Brooklyn, Brooklyn, NY. $L b$. casei ATCC 7469, Lb. paracasei 6A and kombucha were prepared in skimmed milk $(12 \%$ $\mathrm{TS}$, heat treated at $121^{\circ} \mathrm{C}$ for $10 \mathrm{~min}$.) at a rate of $1 \%$ and incubated at $37^{\circ} \mathrm{C}$ for 3 days for activation the cultures before using in the novel functional yoghurts.

\section{Nonfat dry milk (NFDM)}

Instant nonfat dry milk was purchased from RYT-way industries LLC. Lakeville, MN, USA.

\section{Angiotensin converting enzyme}

The Angiotensin converting enzyme was prepared from rabbit lung according to the method described by Cushman and Cheung (1971).

\section{Methods}

\section{Manufacture of yoghurt}

Yoghurt was manufactured according to the method described by Berber (2011) with some modifications as follows: Yoghurt mix was standardized to $4 \%$ fat using cream $23 \%$ fat and $16 \%$ T.S using NFDM, homogenized at 2300 and 500 psi using a Lab 100 M-G homogenizer (LubeckSchlutut, Germany), and then heated at $92^{\circ} \mathrm{C}$ for $30 \mathrm{sec}$ using an AVP Junior HTST system (Tonawanda, NY). Heated yoghurt mix was cooled to $\left(45 \pm 1{ }^{\circ} \mathrm{C}\right)$, divided into four portions. The $1^{\text {st }}$ portion was served as control, the $2^{\text {nd }}$ portion was made with $L b$. casei ATCC $7469\left(\mathrm{~T}_{1}\right)$, the $3^{\text {rd }}$ portion was made with $L b$. paracasei $6 \mathrm{~A}\left(\mathrm{~T}_{2}\right)$ and the $4^{\text {th }}$ portion was made using kombucha $\left(T_{3}\right)$. Yoghurt starter was added at a rate of $1 \mathrm{~g} / 1000 \mathrm{ml}$ of milk in all treatments. The mixtures were filled in $120 \mathrm{~g}$ plastic cups (sterilized using UV light in biosafety hood for 2 hr.) and incubated at $\sim 42 \pm 1{ }^{\circ} \mathrm{C}$ until the $\mathrm{pH}$ reached 4.6. All yoghurt treatments were stored at $4^{\circ} \mathrm{C}$ and analyzed for, chemical, microbiological, rheological and ACE-inhibitory activity properties when fresh and after 7, 14, 21 and 28 days.

\section{Chemical analyses}

Yoghurt treatments were analyzed for fat, total solids (TS) and protein contents according to the International Dairy Federation (IDF) Standards 1991 a, 1991 b and 1993, respectively. $\mathrm{pH}$ values of yoghurt samples were measured using a $\mathrm{pH}$ meter Mettiler Toledo model seven easy, USA according to the method described by BSI (1985). 


\section{Physical Properties}

\section{Penetrometer reading}

Penetrometer reading of all the produced novel functional yoghurt was measured according to Dixon and Parekh (1980) using Humboldt MFG testing equipment, laboratory apparatus, USA. Weight of cone is 35 g., cone angel $45^{\circ}$ and penetration depth was measured after $3 \mathrm{sec}$. the recorded penetrometer readings were expressed as $0.1 \mathrm{~mm} / \mathrm{sec}$.

\section{Water holding capacity}

Water holding capacity of yoghurt treatments was evaluated according to the method described by Sodini et al, (2005), as follows, $20 \mathrm{~g}$ of yoghurt sample (S) were centrifuged for $10 \mathrm{~min}$ at $4000 \mathrm{rpm}$ at $4^{\circ} \mathrm{C}$. The whey expelled (W) was removed and weighed. The water holding capacity (WHC, g/ kg) was calculated as follows:

$$
\mathrm{WHC}=((\mathrm{S}-\mathrm{W}) / \mathrm{S}) \times 1000 .
$$

Evaluation of ACE-inhibitory activity of the novel functional yoghurts crude extract

All the novel functional yoghurt treatments extract were prepared as described by Hernández-Ledesma et al. (2004) with some modifications as follows:

$20 \mathrm{~g}$ of yoghurt were heat treated at $90{ }^{\circ} \mathrm{C}$ for 10 min to stop fermentation then cooled at room temperature. The $\mathrm{pH}$ was adjusted to 3.8 with $50 \%$ lactic acid and centrifuged at $7000 \mathrm{~g}$ for 10 min. The $\mathrm{pH}$ of the supernatant was adjusted to 8.3 and centrifuged again under the same conditions. The obtained crude extracts were examined for its ability to inhibit the angiotensin converting enzyme using the method of Cushman and Cheung (1971).

\section{Microbiological examination}

Total bacterial counts of all yoghurt samples were determined when fresh and all over the storage periods according to the methods of IDF (1991c).

\section{Statistical Analysis}

Data were analyzed for analysis of variance according to Clarke and Kempson (1997) using Statistical Package for the Social Sciences (SPSS) software (version 19.0).

\section{RESULTS AND DISCUSSION}

\section{Coagulation Time}

Data in Table 1 show the coagulation time of all the manufactured novel functional yoghurt treatments. It can be noticed that the control recorded the shortest time of coagulation followed by $T_{3}$. On the other hand, $T_{1}$ and $T_{2}$ recorded the longest coagulation time. The (\%) increase of coagulation time was 19.92, 19.06 and 11.06 for $T_{1}, T_{2}$ and $T_{3}$, respectively. Similar results were recorded by Abdou et al. (2015), who attributed the increase in coagulation time to the possible inhibition of the starter culture in the presence of probiotic bacteria. Moreover Vinderola et al. (2002) observed that probiotic bacteria delay the growth of starter culture.

Statistical analysis of coagulation time showed that, there were non-significant differences between control and $T_{3}$, but there were significant differences between control and $\left(\mathrm{T}_{1}\right.$ and $\left.\mathrm{T}_{2}\right)$. On the other hand, there were non-significant differences between $T_{3}$ and $\left(T_{1}\right.$ and $\left.T_{2}\right)$.

\section{Total Solids}

The results of the total solid contents of all yoghurt treatments (Table 2) of the same storage periods were closed to each other. Also, there was a slightly increase of the total solids for all the treatments along the storage. These results are in agreement with that of El-Nagar and Shenana (1998) and El-Sonbaty et al. (2008) who reported that there was a slight increase in the total solids of yoghurt due to loss of some moisture during cold storage.

The main effect of storage periods showed a significant differences for T.S (\%) when fresh and after 7 days of storage, but there were nonsignificant differences at 14, 21 and 28 days of storage, Also, there were non-significant differences between treatments $(\mathrm{p}=0.741)$.

\section{Fat Content}

The results of fat content (Table 2) showed that there were non pronounced differences between the control and the other treatments either when fresh or during the different storage periods. Moreover, there was a slight increase in the fat content during the storage perioeds and 
Table 1. Coagulation time of novel functional yoghurts

\begin{tabular}{lcc}
\hline Treatment & Coagulation time (hrs: min.) & (\%) of increase in coagulation time \\
\hline Control & $3: 45$ & --- \\
$\mathbf{T}_{\mathbf{1}}$ & $4: 41$ & 19.92 \\
$\mathbf{T}_{\mathbf{2}}$ & $4: 38$ & 19.06 \\
$\mathbf{T}_{\mathbf{3}}$ & $4: 13$ & 11.06 \\
\hline
\end{tabular}

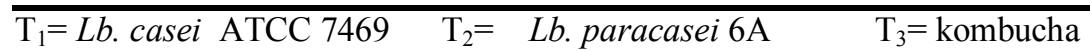

Table 2. Gross chemical composition of the produced novel functional yoghurt samples during storage periods at $4^{\circ} \mathrm{C}$ up to 28 days

\begin{tabular}{|c|c|c|c|c|}
\hline \multicolumn{5}{|c|}{ Treatment } \\
\hline Storage period (day) & Control & $\mathbf{T}_{1}$ & $\mathbf{T}_{2}$ & $\mathbf{T}_{3}$ \\
\hline \multicolumn{5}{|c|}{ Total solids (\%) } \\
\hline Fresh & $16.08^{\mathrm{a}}$ & $15.97^{\mathrm{a}, \mathrm{b}}$ & $16.02^{\mathrm{a}}$ & $15.87^{\mathrm{b}}$ \\
\hline 7 days & $16.20^{\mathrm{a}}$ & $16.14^{\mathrm{a}}$ & $16.17^{\mathrm{a}}$ & $16.02^{\mathrm{b}}$ \\
\hline 14 days & $16.29^{\mathrm{a}}$ & $16.26^{\mathrm{a}}$ & $16.27^{\mathrm{a}}$ & $16.20^{\mathrm{a}}$ \\
\hline 21 days & $16.24^{\mathrm{a}}$ & $16.25^{\mathrm{a}}$ & $16.24^{\mathrm{a}}$ & $16.19^{\mathrm{a}}$ \\
\hline 28 days & $16.23^{\mathrm{a}}$ & $16.22^{\mathrm{a}}$ & $16.19^{\mathrm{a}}$ & $16.15^{\mathrm{a}}$ \\
\hline \multicolumn{5}{|c|}{ Fat $(\%)$} \\
\hline Fresh & $4.07^{\mathrm{a}}$ & $3.83^{\mathrm{b}}$ & $4.03^{\mathrm{a}}$ & $3.73^{\mathrm{b}}$ \\
\hline 7 days & $4.13^{\mathrm{a}}$ & $4.03^{\mathrm{a}}$ & $4.17^{\mathrm{a}}$ & $3.97^{\mathrm{a}}$ \\
\hline 14 days & $4.27^{\mathrm{a}}$ & $4.20^{\mathrm{a}}$ & $4.20^{\mathrm{a}}$ & $4.07^{\mathrm{a}}$ \\
\hline 21 days & $4.30^{\mathrm{a}}$ & $4.23^{\mathrm{b}}$ & $4.27^{\mathrm{a}}$ & $4.13^{\mathrm{b}}$ \\
\hline 28 days & $4.37^{\mathrm{a}}$ & $4.30^{\mathrm{a}, \mathrm{b}}$ & $4.33^{\mathrm{a}, \mathrm{b}}$ & $4.17^{\mathrm{b}}$ \\
\hline \multicolumn{5}{|c|}{ Protein (\%) } \\
\hline Fresh & $4.34^{\mathrm{a}}$ & $4.26^{\mathrm{a}}$ & $4.29^{\mathrm{a}}$ & $4.27^{\mathrm{a}}$ \\
\hline 7 days & $4.49^{\mathrm{a}}$ & $4.41^{\mathrm{a}, \mathrm{b}}$ & $4.39^{\mathrm{b}}$ & $4.38^{\mathrm{b}}$ \\
\hline 14 days & $4.53^{\mathrm{a}}$ & $4.54^{\mathrm{a}}$ & $4.48^{\mathrm{a}}$ & $4.48^{\mathrm{a}}$ \\
\hline 21 days & $4.46^{\mathrm{a}}$ & $4.44^{\mathrm{a}}$ & $4.41^{\mathrm{a}}$ & $4.42^{\mathrm{a}}$ \\
\hline 28 days & $4.41^{\mathrm{a}}$ & $4.37^{\mathrm{a}}$ & $4.36^{\mathrm{a}}$ & $4.33^{\mathrm{a}}$ \\
\hline \multicolumn{5}{|c|}{ Soluble nitrogen/total nitrogen (\%) } \\
\hline Fresh & $1.18^{\mathrm{c}}$ & $2.12^{\mathrm{a}}$ & $2.27^{\mathrm{a}}$ & $1.80^{\mathrm{b}}$ \\
\hline 7 days & $1.42^{\mathrm{d}}$ & $2.16^{\mathrm{b}}$ & $2.67^{\mathrm{a}}$ & $1.84^{\mathrm{c}}$ \\
\hline 14 days & $1.58^{\mathrm{c}}$ & $2.25^{\mathrm{b}}$ & $2.81^{\mathrm{a}}$ & $2.11^{\mathrm{b}}$ \\
\hline 21 days & $1.78^{\mathrm{b}}$ & $2.89^{\mathrm{a}}$ & $3.10^{\mathrm{a}}$ & $2.87^{\mathrm{a}}$ \\
\hline 28 days & $1.87^{\mathrm{b}}$ & $3.40^{\mathrm{a}}$ & $3.52^{\mathrm{a}}$ & $3.35^{\mathrm{a}}$ \\
\hline
\end{tabular}

$\mathrm{T}_{1}=$ Lb. Casei $\quad \mathrm{T}_{2}=$ Lb. paracasei $\quad \mathrm{T}_{3}=$ kombucha

Means at the same row with different superscripts are different $(\mathrm{P}<0.05)$ 
this could be attributed to the high total solids as a result of some moisture evaporation (Basiony et al., 2015). Parallel trends were showed by Badawi et al. (2004), El-Sonbaty et al. (2008) and El-Alfy et al. (2011).

The statistical analysis showed that there were significant differences between interventions. Moreover, there were significant differences between interventions and storage periods. There were significant differences between all the yoghurt treatments when fresh, 21 and 28 days of storage but there were nonsignificant differences between interventions at 7 and 14 days of storage.

\section{Protein Content}

Data of protein content (Table 2) of the novel functional yoghurt treatments during the storage periods showed that there was a slight change between control and the other treatments at the same storage period. The protein content of yoghurts was slightly increased after 14 days of storage; and this increase might be due to the increase of the total solids. These results are in agreement with Kebary et al. (2004), Mahmoud (2005), Shenana et al. (2007) and El-Alfy et al. (2011).

By the end of storage period (28 days) a slight decline of protein content was recorded in all the treatments with different rates than the control and this may be due to the proteolytic effect of the added starter culture (Abdou et al., 2015).

Statistically, the storage periods showed significant differences of the protein content between the interval storage periods, but, there were non-significant differences between interventions and storage periods.

\section{Soluble Nitrogen/Total Nitrogen (SN/TN)}

The results (SN/TN) of all the novel functional yoghurts during the storage periods (Table 2 and Fig. 1) revealed that the control had low values in a comparison to other treatments at the same storage periods. This might be due to the ability of the used microorganisms to hydrolyze the protein more than the microorganisms of starter culture resulting higher soluble nitrogen.

The soluble nitrogen content increased during the cold storage periods of all treatments, but the control recorded the lowest values. These results are in agreement with Papadimitriou et al. (2007), Hussien (2010) and Abdou et al. (2015).

The storage periods showed significant differences of the interval storage periods, also the different treatments showed that there were significant differences between interventions. Moreover, there were significant differences for the interaction between interventions and storage periods.

\section{pH Values}

The impact of adding other lactic acid bacteria beside the starter culture, i.e. Lb. casei ATCC $7469, L b$. paracasei $6 \mathrm{~A}$ and kombucha at a rate of $3 \%$ on $\mathrm{pH}$ values is recorded in Table 3 .

The $\mathrm{pH}$ values were decreased along the storage periods, which reflect the development of acidity by the activity of the used microorganisms either starter culture or probiotic microorganisms. These results agree with those reported by El-Alfy (1988), ElSonbaty et al. (2008) and El-Alfy et al. (2011).

Statistical analysis of the $\mathrm{pH}$ data showed the significant differences in the $\mathrm{pH}$ levels at different storage periods for all treatments compared with the control, there were nonsignificant differences between the intervals storage periods of the control and $\mathrm{T}_{3}$.

\section{Water Holding Capacity (WHC)}

Water holding capacity (WHC) is a character used as indicator of how much water can be reserved in yoghurt. The most important factors which affect the WHC are the total solids (especially proteins and fat contents), the starter culture (either ropy or non-ropy) and manufacturing conditions of yoghurt (Chandan et al., 2006). From the obtained results it is clear that the WHC was increased with the increase of total solids and decreases with the decrease of total solids. Also the obtained data reflect the structure of the product which depends on the chemical composition (Lucey, 2004).

Statistical analysis for WHC showed that there were significant differences between all the produced yoghurt when fresh, 7 and 14 days of storage, respectively, but there were nonsignificant differences after 21 and 28 days of storage. Also, storage periods had no significant effect on the WHC for $\mathrm{T}_{1}$. 


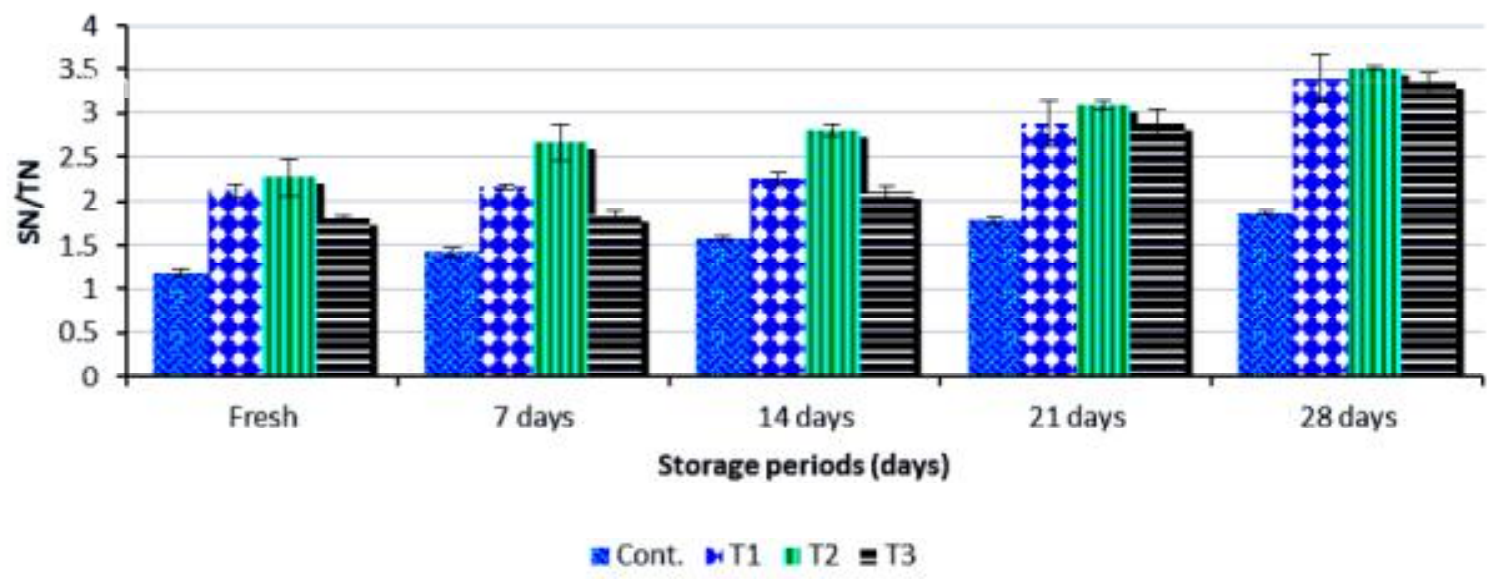

Fig. 1. Change of the soluble nitrogen/total nitrogen (\%) of novel functional yoghurts during the storage periods at $4^{\circ} \mathrm{C}$ up to 28 days

Table 3. Change in the pH values of novel functional yoghurts during storage periods at $4^{\circ} \mathrm{C}$ up to 28 days

\begin{tabular}{lcccc}
\hline Storage period (day) & \multicolumn{3}{c}{ Treatment } \\
\cline { 2 - 5 } & Control & $\mathbf{T}_{\mathbf{1}}$ & $\mathbf{T}_{\mathbf{2}}$ & $\mathbf{T}_{\mathbf{3}}$ \\
\hline Fresh & $4.62^{\mathrm{a}}$ & $4.58^{\mathrm{a}}$ & $4.59^{\mathrm{a}}$ & $4.60^{\mathrm{a}}$ \\
$\mathbf{7}$ & $4.52^{\mathrm{a}}$ & $4.47^{\mathrm{a}}$ & $4.46^{\mathrm{a}}$ & $4.53^{\mathrm{a}}$ \\
$\mathbf{1 4}$ & $4.49^{\mathrm{a}}$ & $4.39^{\mathrm{b}}$ & $4.38^{\mathrm{b}}$ & $4.48^{\mathrm{a}}$ \\
$\mathbf{2 1}$ & $4.46^{\mathrm{a}}$ & $4.33^{\mathrm{b}}$ & $4.31^{\mathrm{b}}$ & $4.41^{\mathrm{a}}$ \\
$\mathbf{2 8}$ & $4.39^{\mathrm{a}}$ & $4.28^{\mathrm{b}}$ & $4.20^{\mathrm{b}}$ & $4.33^{\mathrm{a}}$ \\
\hline
\end{tabular}

$\mathrm{T} 1=$ Lb. case $i$ ATCC $7469 \quad \mathrm{~T} 2=\quad$ Lb. paracasei $6 \mathrm{~A} \quad \mathrm{~T} 3=$ kombucha

Means at the same row with different superscripts are different $(\mathrm{P}<0.05)$

Table 4. Change in the WHC of novel functional yoghurts during storage periods at $4^{\circ} \mathrm{C}$ up to 28 days

\begin{tabular}{lcccc}
\hline Storage period (day) & \multicolumn{4}{c}{ Treatment } \\
\cline { 2 - 5 } & Control & $\mathbf{T}_{\mathbf{1}}$ & $\mathbf{T}_{\mathbf{2}}$ & $\mathbf{T}_{\mathbf{3}}$ \\
\hline Fresh & $790.83^{\mathrm{a}}$ & $763.17^{\mathrm{b}}$ & $766.67^{\mathrm{b}}$ & $795.17^{\mathrm{a}}$ \\
$\mathbf{7}$ & $794.00^{\mathrm{a}}$ & $765.33^{\mathrm{c}}$ & $771.50^{\mathrm{b}}$ & $798.50^{\mathrm{a}}$ \\
$\mathbf{1 4}$ & $798.50^{\mathrm{a}}$ & $768.67^{\mathrm{b}}$ & $773.17^{\mathrm{b}}$ & $752.67^{\mathrm{c}}$ \\
$\mathbf{2 1}$ & $791.33^{\mathrm{a}}$ & $762.50^{\mathrm{a}}$ & $765.83^{\mathrm{a}}$ & $767.00^{\mathrm{a}}$ \\
$\mathbf{2 8}$ & $784.67^{\mathrm{a}}$ & $770.83^{\mathrm{a}}$ & $759.00^{\mathrm{a}}$ & $790.17^{\mathrm{a}}$ \\
\hline
\end{tabular}

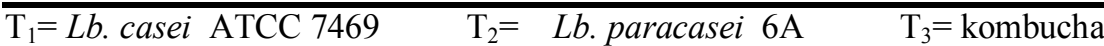

Means at the same row with different superscripts are different $(\mathrm{p}<0.05)$ 


\section{Angiotensin Converting Enzyme Inhibition (\%) (ACE- inhibition \%)}

Bioactive peptides could be liberated during the fermentation of milk using different microorganisms of starter cultures which contain several proteolytic enzymes that are responsible for the breakdown of the protein resulting peptides and amino acids depending on the degree of hydrolysis (Meisel et al., 1997).

The hydrolysates of peptides and amino acid sequence (bioactive peptides) have the ability to inhibit the ACE. The maximum ACE inhibition by these bioactive peptides is a result of the hydrolysate (Van der ven et al., 2002). Using of lactic acid bacteria in making some dairy products i.e yoghurt one of the famous technique for producing these bioactive peptides.

Table 5 and Fig. 2 show the results of ACEinhibition (\%) of novel functional yoghurts extracts during the storage periods. From the recorded data it can be noticed that there were differences between the control and the other treatments. The control extracts recorded the lowest ACE-inhibition (\%), either when fresh or during the interval storage periods in a comparison with the other treatments. Similar results were obtained by Solieri et al. (2015). The ACE-inhibition (\%) increased during the storage periods. The increase of the ACEinhibition (\%) of $\mathrm{T}_{1}, \mathrm{~T}_{2}$ and $\mathrm{T}_{3}$ might be due to the ability of the used microorganisms to liberate bioactive peptides from milk proteins during fermentation process. These results are in agreement with Papadimitriou et al. (2007). It is good to mention that the (\%) soluble nitrogen was having the trend of increasing during the storage periods, in contrast with storage progress gave a chance to the lactic acid bacteria, the added strains and kombucha to increase protease enzymes which gave more soluble proteins (Table 2) and more active peptides which increase the inhibit of the ACE. The obtained results are in accordance with Ryhänen et al. (2001) and Van der ven et al. (2002) who found that the ACE-inhibitory activity of liberated bioactive peptides from milk fermented products could be decreased when proteolysis exceeded a certain level. So, the higher bioactive peptides the higher ACE-inhibition (\%). From the forgoing results the produced novel functional yoghurt could be serve as high ACE-inhibitory.

Statistical analysis of (\%) ACE-inhibition showed that the (\%) ACE-inhibition increased over storage periods, but less in the control. The main effect of storage periods showed significant differences in the (\%) ACEinhibition at different storage periods. Moreover, there were significant differences in the (\%) ACE-inhibition between interventions. Also there were statistically significant interaction between interventions and storage periods.

\section{Firmness}

The penetration readings of novel functional yoghurts give indications about the structure, homogeneity, consistency and tension of the produced gel. Results in Fig. 3 show the penetrometer readings $(0.1 \mathrm{~mm} / \mathrm{sec}$.) of yoghurts during the storage periods. From the results it can be observed that the firmness of $\mathrm{T}_{3}$ was higher than control and other treatments. This result is in agreement with El-Alfy et al. (2011).

The penetrometer reading of yoghurts recorded 231, 226, 228 and 216 for control to $\mathrm{T}_{3}$, respectively, when fresh. It is going to be decreased among the treatments with different rates along the cold storage up to 14 days of storage according to the changes in the nature and protein content. These results are in accordance with those obtained by Abdou et al. (2015) as they attributed the decrease of penetrometer reading and hence the increase of firmness to continuous protein rearrangement and more protein-protein interaction which would increase the viscosity and firmness of yoghurt during the cold storage as affected by the type of starter. Also it can be noticed that there was a little bit increase in the penetrometer reading in 21 and 28 days of cold storage, this may be due to the hydrolysis of casein. These results are in agreement with Shenana et al. (2007) and El-Alfy et al. (2011).

From statistical analysis of penetrometer readings data, it was found that the main effect of storage periods had statistical significant differences at different storage periods, also the main effect of treatments showed that there were statistically significant differences between 
Table 5. Change of the *ACE-inhibition (\%) of yoghurts extracts during the storage periods at $4^{\circ} \mathrm{C}$ up to 28 days

\begin{tabular}{|c|c|c|c|c|c|c|c|}
\hline \multirow[t]{3}{*}{ Storage period (day) } & \multicolumn{7}{|c|}{ Treatment } \\
\hline & \multirow[t]{2}{*}{ Control } & \multicolumn{2}{|c|}{$\mathbf{T}_{1}$} & \multicolumn{2}{|c|}{$\mathbf{T}_{2}$} & \multicolumn{2}{|c|}{$\mathbf{T}_{3}$} \\
\hline & & $\begin{array}{c}\%) \\
\text { Inhibition }\end{array}$ & $\begin{array}{l}\% *(\%) \\
\text { Increase }\end{array}$ & $\begin{array}{c}\mathbf{( \% )} \\
\text { Inhibition }\end{array}$ & $\begin{array}{c}* \%(\%) \\
\text { Increase }\end{array}$ & $\begin{array}{c}\%) \\
\text { Inhibition }\end{array}$ & $\begin{array}{c}* *(\%) \\
\text { Increase }\end{array}$ \\
\hline Fresh & $39.26^{\mathrm{d}}$ & $75.76^{\mathrm{a}}$ & 48.17 & $67.98^{b}$ & 42.24 & $59.20^{\mathrm{c}}$ & 33.68 \\
\hline 7 & $40.86^{\mathrm{c}}$ & $80.16^{\mathrm{a}}$ & 49.02 & $76.53^{\mathrm{a}}$ & 46.60 & $62.25^{\mathrm{b}}$ & 34.36 \\
\hline 14 & $47.14^{\mathrm{c}}$ & $92.25^{\mathrm{a}}$ & 48.89 & $86.69^{b}$ & 45.62 & $87.22^{b}$ & 45.95 \\
\hline 21 & $54.28^{c}$ & $92.97^{\mathrm{a}}$ & 41.61 & $88.55^{\mathrm{b}}$ & 38.70 & $89.92^{b}$ & 39.63 \\
\hline 28 & $63.96^{\mathrm{c}}$ & $96.61^{\mathrm{a}}$ & 33.79 & $88.59^{b}$ & 27.80 & $89.96^{\mathrm{b}}$ & 28.90 \\
\hline
\end{tabular}

$\mathrm{T} 1=$ Lb. casei $\mathrm{ATCC} 7469 \quad \mathrm{~T} 2=\quad$ Lb. paracasei $6 \mathrm{~A} \quad \mathrm{~T} 3=$ kombucha

*ACE $=$ Angiotensin converting enzyme, the activity of the used enzyme is 0.008 unit.

** (\%) increase in comparison to the control.

Means at the same row with different superscripts are different $(\mathrm{p}<0.05)$

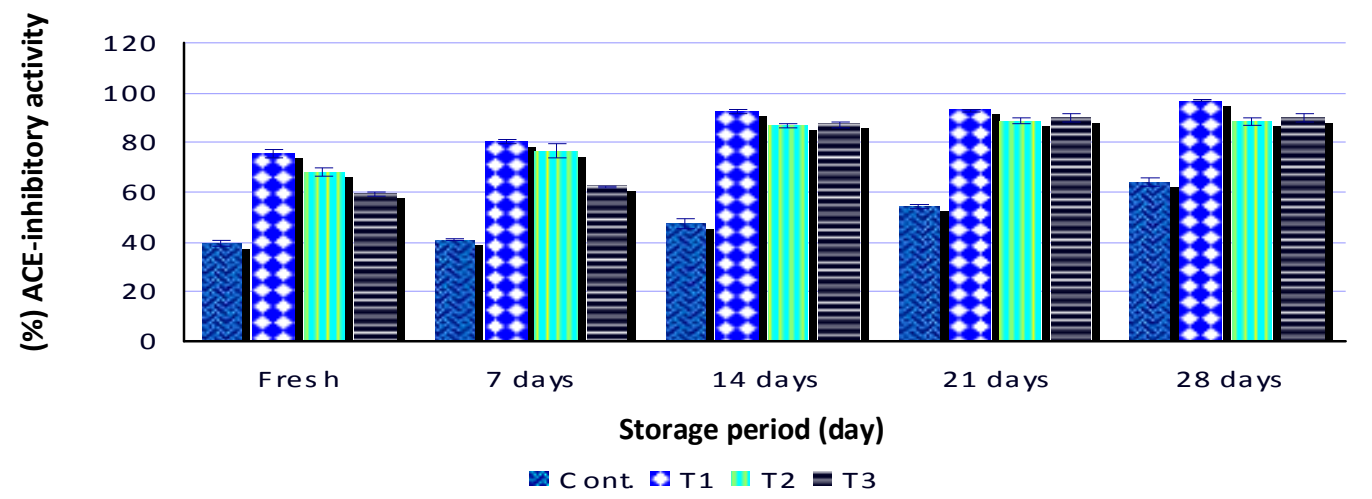

Cont. $=$ control $\quad \mathrm{T} 1=$ Lb. casei $\mathrm{ATCC} 7469 \quad \mathrm{~T} 2=$ Lb. paracasei $6 \mathrm{~A} \quad \mathrm{~T} 3=$ kombucha

Fig. 2. Change of the ACE-inhibition (\%) of yoghurts extracts during the storage periods at $4^{\circ} \mathrm{C}$ up to 28 days

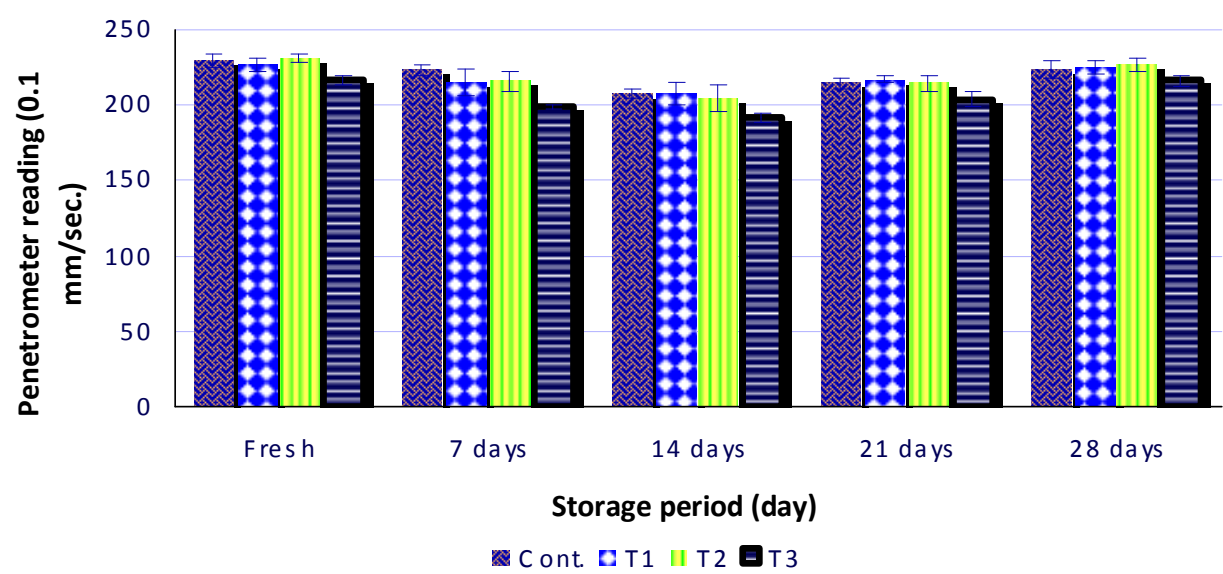

Fig. 3. Change in the penetrometer reading $(0.1 \mathrm{~mm} / \mathrm{sec}$.) of yoghurts during storage periods at $4^{\circ} \mathrm{C}$ up to 28 days 
interventions, but there were no statistically significant interaction between interventions and storage periods $(\mathrm{P}=0.364)$. There were no statistical significance differences between interventions at the end of storage periods $(\mathrm{P}=0.068)$.

\section{Total Viable Microorganisms Count} (TVC) of the Produced Novel Functional Yoghurt (log cfu/g) During the Storage Periods up to 28 Days

Data in Table 6 and Fig. 4 indicate the microorganisms counts of the produced novel yoghurts during the storage periods. The recorded counts (log cfu/g) of yoghurts microorganisms increased after 7 days of storage, then decreased up to the end of the storage periods. These results are in agreement with Abd El-Salam et al. (1991), Barrantes et al. (1994) and El-Alfy et al. (2011).

From statistical analysis point of view TVC of the novel functional yoghurts microorganisms showed that the main effect of storage periods had significant differences at different storage periods. Also, there were statistically significant differences between interventions. Moreover there was significant interaction between interventions and the cold storage periods.

Table 6. Total viable microorganisms count (TVC) of novel functional yoghurts (log $\mathrm{cfu} / \mathrm{g}$ ) during the storage periods at $4{ }^{\circ} \mathrm{C}$ up to 28 days

\begin{tabular}{lcccc}
\hline Storage periods (days) & \multicolumn{5}{c}{ Treatments } \\
\cline { 2 - 5 } & Control & $\mathbf{T}_{\mathbf{1}}$ & $\mathbf{T}_{\mathbf{2}}$ & $\mathbf{T}_{\mathbf{3}}$ \\
\hline Fresh & $8.4^{\mathrm{b}}$ & $9.2^{\mathrm{a}}$ & $9.0^{\mathrm{a}}$ & $8.6^{\mathrm{b}}$ \\
$\mathbf{7}$ & $8.8^{\mathrm{b}}$ & $9.7^{\mathrm{a}}$ & $9.7^{\mathrm{a}}$ & $9.5^{\mathrm{a}}$ \\
$\mathbf{1 4}$ & $6.6^{\mathrm{c}}$ & $9.0^{\mathrm{a}}$ & $9.0^{\mathrm{a}}$ & $8.7^{\mathrm{b}}$ \\
$\mathbf{2 1}$ & $5.9^{\mathrm{c}}$ & $8.8^{\mathrm{a}}$ & $8.8^{\mathrm{a}}$ & $8.1^{\mathrm{b}}$ \\
$\mathbf{2 8}$ & $5.6^{\mathrm{c}}$ & $8.6^{\mathrm{a}}$ & $8.6^{\mathrm{a}}$ & $8.0^{\mathrm{b}}$ \\
\hline
\end{tabular}

$\mathrm{T} 1=$ Lb. casei $\mathrm{ATCC} 7469 \quad \mathrm{~T} 2=\quad$ Lb. paracasei $6 \mathrm{~A} \quad \mathrm{~T} 3=$ kombucha

Means at the same row with different superscripts are different $(\mathrm{p}<0.05)$.

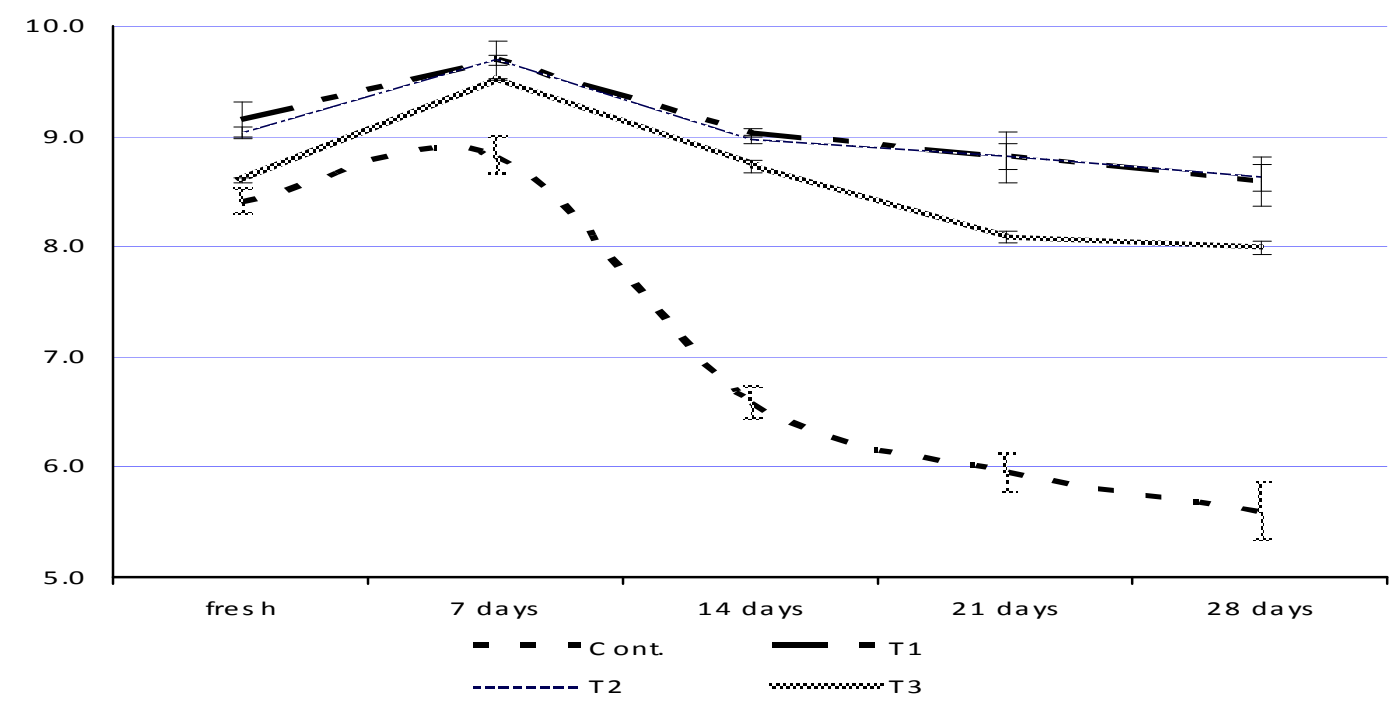

Fig. 4. Total viable microorganisms count of novel functional yoghurts (log cfu/g) during the storage periods at $4^{\circ} \mathrm{C}$ up to 28 days 


\section{Conclusions}

From the forgoing results, we could conclude that the use of $L b$. casei ATCC 7469, $L b$. paracasei $6 \mathrm{~A}$ and kombucha in the manufacture of yoghurt could introduce novel functional types of yoghurt with ACE-inhibitory activity. The chemical, physical and microbiological characteristics of the produced novel functional yoghurts were as good as the control up to the end of storage periods (28 days).

\section{Acknowledgement}

We would like to thank the Cultural Affairs and Missions Sector, Ministry of Higher Education and Scientific Research, Egypt, for funding and supporting this study.

\section{REFERENCES}

Abd El-Salam, M.H., S. El-Shibiny, M.B. Mahfouz, H.F. El-Dein, H.M. El-Atrby and V. Antila (1991). Preparation of whey protein concentrate from salted whey and its use in yoghurt. J. Dairy Res., 53: 503-510.

Abdou, S.M., M.E. Shenana, N.M. Mansour and M.A. Zakaria (2015). Making bioyoghurt using newly isolated lactic acid bacteria with probiotic features. Egyptian J. Dairy Sci. (supplement presented in the $12^{\text {th }}$ Egypt. Conf. Dairy Sci. and Technol., Cairo, 9-11 Nov., 239-253.

Badawi, R.M., K.M.K. Kebary and S.A. Hussein (2004). Impact of substituting non-fat dry milk with pectin on cow's milk yoghurt quality. The $9^{\text {th }}$ Egyptian Conf. for Dairy Sci. and Tech. "milk and dairy products for a healthy future" Dokki, 9-11 October, Cairo, Egypt.

Barrantes, E., A.Y. Tamime, D.D. Muir and A.M. Sword (1994). The effect of substitution of fat by microparticulate whey protein on the quality of set-type, natural yoghurt. Soc. Dairy Technol., 47: 61-68.

Basiony, M.M.M., M.N.F. Hamad and M.M. Ismail (2015). Effect of fortification with texturized soy protein on the chemical, microbial and sensorial attributes of labneh made from goats milk. Egyptian J. Dairy Sci. (supplement presented in the $12^{\text {th }}$ Egypt.
Conf. Dairy Sci. and Technol., Cairo, 9-11 Nov., 227-237.

Berber, M. (2011). Whey protein concentrate as a substitute for non-fat dry milk in yoghurt, M.Sc., The Ohio State Univ., USA.

BSI (1985). British Standards Institution. Dtermination of $\mathrm{pH}$ value. BS770 part 5 .

Chandan, R.C., C.H. White, A. Kilara and Y.H. Hui (2006). Manufacturing Yoghurt and Fermented Milks $\left(1^{\text {st }}\right.$ Ed). Blackwell Publishing.

Clarke, G.M. and R.E. Kempson (1997). Introduction to The Design And Analysis of Experiments. Arnold, A member of the hoplder Headline Group, $1^{\text {st }}$ Eds., London, UK.

Cushman, D.W. and H.S. Cheung (1971). Spectrophotometric assay and properties of the angiotensin-converting enzyme of rabbit lung. Bioch. Pharmacol., 20: 1637-1648.

Dixon, B.D. and J.V. Parekh (1980). The use of cone penetrometer for testing the firmness of butter. J. Texture Studies, 10 (4): 421-434.

Donkor, O.N., A. Henriksson, T. Vasiljevic and N.P. Shah (2005). Probiotic strain as starter cultures improve angiotensing enzyme inhibitory activity in soy yoghurt. J. Food Sci., 70 (8): M375-M381.

El-Alfy, M.B. (1988). Trails on accelerating cheese ripenning. Ph.D. Thesis, Moshtohor, Benha Branch, Zagazig Univ. Egypt.

El-Alfy, M.B., M.E. Shenana, M.A. Abd El-aty and E.S. Elkhtab (2011). Antibacterial activity of some natural preservative materials and their effect on characteristics of yoghurt. Egyptian J. App. Sci., $26: 12$.

El-Nagar, G.F. and M.E. Shenana (1998). Production and acceptability of bioyoghurt. Proc. $7^{\text {th }}$ Egyptian Conf. Dairy Sci. and Tech., 227-240., Dokki, Cairo, Egypt.

El-Sonbaty, A.H., K.M.K. Kebary, R.M. Badawy and A.E. Hweda (2008). Effect of stabilizers on the quality of stirred yoghurt. Egyptian J. Dairy Sci., 36: 185-195.

FitzGerald, R.J. and H. Meisel (2003). Milk Protein Hydrolysates and Bioactive Peptides. In: PF. Fox, and PLH McSweeney (Eds.), 
Advanced dairy chemistry, Vol. 1: Proteins $\left(3^{\text {rd }}\right.$ Ed.). New York, NY, USA: Kluwer Academic/Plenum Publishers, 675-698

Fuglsang, A., F.P. Rattray, D. Nilsson and N.C.B. Nyborg (2003). Lactic acid bacteria: Inhibition of angiotensin converting enzyme in vitro and in vivo. Antonie van Leeuwenhoek, 83: 27-34.

Gobbetti, M., F. Minervini and C.G. Rizzello (2004). Angiotensin I-converting-enzymeinhibitory and antimicrobial bioactive peptides. Int. J. Dairy Technol., 57: 172-188.

Gomez-Ruiz, J.A., M. Ramos and I. Recio (2002). Angiotensin-converting enzymeinhibitory peptides in Manchego cheeses manufactured with different starter cultures. Int. Dairy J., 12: 697-706.

Hernández-Ledesma, B., L. Amigo, M. Ramos and I. Recio (2004). Application of high performance liquid chromatography-tandem mass spectrometry to the identification of biologically active peptides produced by milk fermentation and simulated gastrointestinal digestion. J. Chromatography A 1049: 107-114.

Hussein, G.A.M. (2010). Preparation of yoghurt and probiotic yoghurt-like fermentd products for bottle-fed infants. Egyptian J. Dairy Sci., 38: 171-182.

IDF (1991a). Internatinnal dairy federation. milk and milk products: Determination of fat content. guidance on the use of butyromtric methods: IDF 151.

IDF (1991b). Internatinnal dairy federation yoghurt: Determination of total solids content IDF, 151.

IDF (1991c). Internatinnal dairy federation. Milk and milk products: Enumiration of microorganisms colony count technique at $30^{\circ} \mathrm{C}$. IDF 100B.

IDF (1993). Internatinnal dairy federation Milk: Determination of nitrogen content IDF: 20B.

Kebary, K.M.K., S.A. Hussein and R.M. Badawi (2004). Impact of fortification of cow's milk with a modified starch on yoghurt quality. Egyptian J. Dairy Sci., 32: 111-124.
Korhonen, H. (2009). Milk derived bioactive peptides: from science to application. J. Functional Foods. 1(2): 177-187.

Korhonen, H. and A. Pihlanto (2003). Bioactive peptides: Novel applications for milk proteins. Appl. Biotechnol., Food Sci. and Policy, 1 : 133-144.

Lucey, J. A. (2004). Cultured dairy products, an overview of the gelation and texture properties. Int. J. Dairy Technol., 57 (2-3): 77-84.

Mahmoud, S.F. (2005). Influence of substitution non-fat dry milk with locust bean gum on cow's milk yoghurt quality. Minufya J. Agric. Res., 30: 77.

Meisel, H., Goepfert, A. and Gunther, S. (1997). ACE-inhibitory activities in milk products. Milchwissenschaft 52, 307-311.

Meisel, H. and R.J. FitzGerald (2003). Biofunctional peptides from milk proteins: Mineral binding and cytomodulatory effects. Current Pharmaceutical Design, 9 : 12891295.

Migliore-Samour, D. and P. Jolles (1988). Casein prohormone with an immunomodulating role for the newborn. Experientia, 44: 188-193.

Papadimitriou, C.G., A. VafopoulouMastrojiannaki, S.V. Silva, A.M. Gomes, F.X. Malcata and E. Alichanidis (2007). Identification of peptides in traditional and probiotic sheep milk yoghurt with angiotensin I-converting enzyme (ACE)-inhibitory activity. Food Chem., 105: 647-656.

Ryhänen, E.-L., A. Pihlanto-Leppälä and E. Pahkala (2001). A new type of ripened, lowfat cheese with bioactive properties. Int. Dairy J., 11: 441-447.

Shenana, M.E., G.F. El-Nagar, S. El-Shibiny and S.M. Abdou (2007). Preparation and use of whey protein/carrageenan particulate in making low-fat yoghurt. Egyptian J. Dairy Sci., 35: 185-193.

Sodini, I., J. Montella and P.S. Tong (2005). Physical properties of yoghurt fortified with various commercial whey protein concentrates. J. the Sci. Food and Agric., 85 : 853-859. 
Solieri, L., G.S. Rutella and D. Tagliazucchi (2015). Impact of non-starter lactobacilli on release of peptides with angiotensinconverting enzyme inhibitory and antioxidant activities during bovine milk fermentation. Food Microbiol., 51 : 108-116.

Van der ven, C., H. Gruppen, D.B. de Bont and A.G. Voragen (2002). Optimisation of the angiotensin converting enzyme inhibition by whey protein hydrolysates using response surface methodology. Int. Dairy J., 12: 813820 .

Vasudha, S. and H.N. Mishra (2013). Non dairy probiotic beverages. Int. Food Res. J., 20 (1): 7-15.

Vinderola, C.G., P. Mocchiutii and J.A. Reinheimer (2002). Interactions among lactic acid starter and probiotic bacteria used for fermented dairy products. J. Dairy Sci., 85: 721-729.

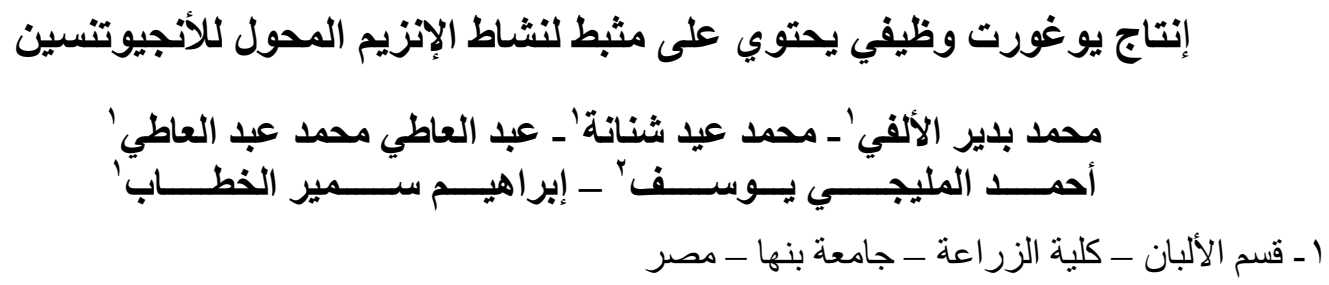

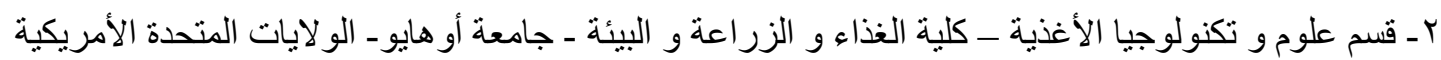

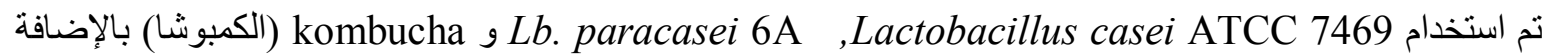

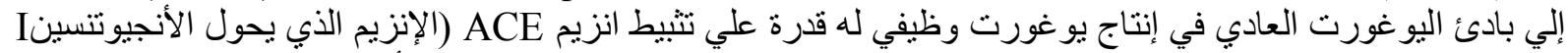

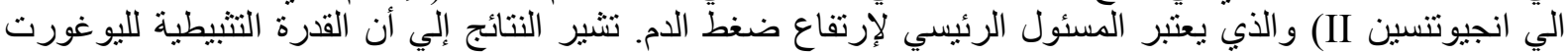

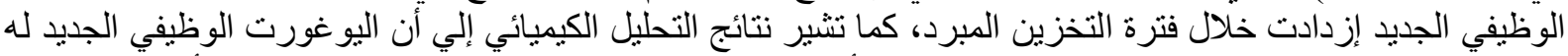

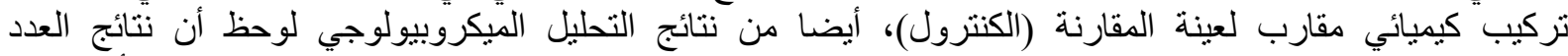

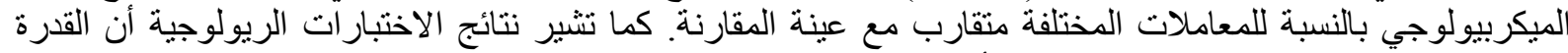
علي الإحتفاظ بالماء و القو ام و التركيب كانت أيضا جيدة في المعاملات المختلفة مثل عينة المقارنة حتي نهاية مدة التخزين

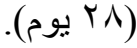

